\title{
Lewis enzyme ( $\alpha 1-3 / 4$ fucosyltransferase) polymorphisms do not explain the Lewis phenotype in the gastric mucosa of a Portuguese population
}

Received: 12 December 2002/ Accepted: 23 January 2003 / Published online: 20 March 2003

(C) The Japan Society of Human Genetics and Springer-Verlag 2003

\begin{abstract}
The human $\alpha-1,3 / 4$ fucosyltransferase III (FucT III) catalyses the synthesis of Lewis antigens including $\mathrm{Le}^{\mathrm{b}}$ antigen which is a ligand for Helicobacter pylori adhesion. Several polymorphisms have been described in the FUT3 gene affecting both the transmembrane and catalytic domains, some of which affect the enzyme activity. The aim of the present work was to study the Lewis gene polymorphisms in a Caucasian Portuguese population, with a high rate of $H$. pylori infection, and to evaluate the implications of mutant enzymes in $\mathrm{Le}^{\mathrm{b}}$ expression in the gastric mucosa. We studied 460 asymptomatic or dyspeptic individuals from northern Portugal. Screening for Lewis gene polymorphisms was performed by SSCP and direct sequencing. Lewis phenotype in gastric mucosa was determined by immunohistochemistry. In 47 individuals with a Lewis negative blood group, we found FUT3 gene polymorphisms that were previously described in other populations: $59 \mathrm{~T}>\mathrm{G}$, $202 \mathrm{~T}>\mathrm{C}, 314 \mathrm{C}>\mathrm{T}, 508 \mathrm{G}>\mathrm{A}$ and $1067 \mathrm{~T}>\mathrm{A}$. Among the 47 Lewis negative individuals in blood, only nine were also negative in gastric mucosa, suggesting the existence of another $\alpha 1-4$ fucosyltransferase that is responsible for $\mathrm{Le}^{\mathrm{a}}$ and $\mathrm{Le}^{\mathrm{b}}$ synthesis in gastric mucosa.
\end{abstract}

J. Serpa $(\varangle) \cdot$ R. Almeida $\cdot$ C. Oliveira · F. S. Silva

E. Silva $\cdot$ C. Reis $\cdot$ L. David

IPATIMUP- Institute of Pathology and Molecular Immunology of the University of Porto,

Rua Dr. Roberto Frias s/n, 4200 Porto, Portugal

E-mail: jserpa@ipatimup.pt

Tel.: + 351-22-5570753

Fax: + 351-22-5570799

L. David

Medical Faculty, University of Porto, Porto, Portugal

J. Le Pendu

INSERM U419, Institute of Biology, Nantes, France

G. Oliveira · L. M. C. Ribeiro

Department of Immunohematology,

Hospital S. João, Porto, Portugal
Keywords Lewis enzyme · Fucosyltransferase ·

Polymorphisms $\cdot$ Lewis antigens $\cdot$ Helicobacter pylori

\section{Introduction}

The human $\alpha-1,3 / 4$ fucosyltransferase III (FucT III) catalyses the transfer of fucose in $\alpha-1,4$ and $\alpha-1,3$ linkages onto type 1 and type 2 core structures, and uses both neutral and sialylated carbohydrates as acceptors (Kokowska-Latallo et al. 1990). FucT III is called the Lewis enzyme since it catalyses the synthesis of Lewis antigens: $\mathrm{Le}^{\mathrm{a}}$, sialyl-Le ${ }^{\mathrm{a}}, \mathrm{Le}^{\mathrm{b}}, \mathrm{Le}^{\mathrm{x}}$, sialyl-Le ${ }^{\mathrm{x}}$ and $\mathrm{Le}^{\mathrm{y}}$ (Kokowska-Latallo et al. 1990). The Lewis histo-blood group system comprises two major antigens, $\mathrm{Le}^{\mathrm{a}}$ and $\mathrm{Le}^{\mathrm{b}}$, whose determinants can be found in large mucin structures or in cell membranes, associated to glycoproteins and glycolipids (Narimatsu 1994). These $\mathrm{Le}^{\mathrm{a}}$ and $\mathrm{Le}^{\mathrm{b}}$ fucosylated glycosphingolipids are synthesised by exocrine epithelial cells (Oriol et al. 1986) and then adsorbed on erythrocyte membranes in peripheral blood leading to the Lewis blood phenotype. The cell surface fucosylated oligosacharides participate in several biological processes such as embryogenesis, tissue differentiation, tumour metastasis, inflammation and bacterial adhesion (SchenkelBrunner 1995).

A fundamental role was attributed to $\mathrm{Le}^{\mathrm{b}}$ and $\mathrm{H}$ type 1 antigens in the adhesion of Helicobacter pylori to gastric mucosa mediated by blood group antigen-binding adhesin, Bab A (Boren et al. 1993; Gerhard et al. 1999; Ilver et al. 1998). A few groups have therefore explored the possibility that the host Lewis phenotype might be determinant for the frequency and characteristics of $H$. pylori infection. The results obtained from these studies gave conflicting results: Heneghan et al. (1998), Oberhuber et al. (1997), Clyne and Drumm (1997), Umlauft et al. (1996) and Niv et al. (1996) did not observe any significant relationship between the expression of $\mathrm{Le}^{\mathrm{b}}$ 
and H. pylori infection, whereas Klaamas et al. (1997) and Carneiro et al. (1996) observed a higher prevalence of $H$. pylori infection in $\mathrm{Le}^{\mathrm{b}}$ positive individuals. A recent study, by Ikehara et al. (2001), brought again into focus the relevance of host Lewis status by demonstrating that polymorphisms of Lewis and Secretor genes affect the susceptibility to $H$. pylori infection.

Several polymorphisms have been described in the FUT3 gene. The 59T $>\mathrm{G}$ polymorphism is localised in the transmembrane domain and does not affect the enzyme activity, though it can switch the FucT III cell localisation from the Golgi apparatus to the cytoplasm (Koda et al. 1993; Mollicone et al. 1994; Narimatsu et al. 1996). All the other polymorphisms described until now are located in the catalytic domain: $202 \mathrm{~T}>\mathrm{C}, 314 \mathrm{C}>\mathrm{T}$, 445C $>$ A, 508G $>$ A, 1067T $>$ A (Elmgren et al. 1996; 1997; Liu et al. 1999; Narimatsu et al. 1996; Nishihara et al. 1999; Ørntoft et al. 1996), 304C $>$ A, 370T $>$ G, $848 \mathrm{G}>\mathrm{A}, 667 \mathrm{G}>\mathrm{A}$ and $808 \mathrm{G}>\mathrm{A}$ (Pang et al. 1996, 1998). These Lewis gene variants codify enzymes with a lower activity $(314 \mathrm{C}>\mathrm{T}, 304 \mathrm{C}>\mathrm{A}$ and $370 \mathrm{~T}>\mathrm{G})$ or an inactive FucT III $(202 \mathrm{~T}>\mathrm{C}, 508 \mathrm{GaA}, 1067 \mathrm{~T}>\mathrm{A}$, $667 \mathrm{G}>\mathrm{A}$ and $808 \mathrm{G}>\mathrm{A}$ ).

The aim of the present work was to study the Lewis gene polymorphisms in a Caucasian population from Northern Portugal, with a high rate of Helicobacter pylori infection, and to evaluate the implications of the mutant enzymes in the profile of $\mathrm{Le}^{\mathrm{b}}$ expression in the gastric mucosa.

\section{Materials and methods}

\section{Population}

In the present study we evaluated 460 asymptomatic or dyspeptic Caucasian individuals from northern Portugal (Nogueira et al. 2001). From each patient biopsy specimens were taken from corpus $(n=1)$ and antrum $(n=2)$. Gastric biopsies for histology studies were fixed in $10 \%$ formalin and routinely embedded in paraffin wax. The histological classification of the biopsies was performed according to the revised version of the Sydney system (Dixon et al. 1996). The frequency of $H$. pylori infection and the characteristics of the infection were available from 360 individuals that were biopsied and part of this information was previously published (Nogueira et al. 2000, 2001). Forty-seven individuals from this population $(10.2 \%)$ had a negative Lewis blood group phenotype $\left(\mathrm{Le}^{\mathrm{a}-\mathrm{b}-}\right)$ and were evaluated for FUT3 gene polymorphisms and for the profile of $\mathrm{Le}^{\mathrm{a}}$ and $\mathrm{Le}^{\mathrm{b}}$ expression in the gastric mucosa.

Screening of polymorphisms of the FUT3 gene

The screening of FUT3 polymorphisms in the 47 Lewis negative individuals was performed whenever possible by SSCP (single strand conformation pattern).

Polymerase chain reaction (PCR)

The primers used to amplify the FUT3 fragments are presented in Table 1. Five fragments spanning most of the coding sequence of the FUT3 gene were obtained. For the fifth fragment, two different sets of primers were used, FUT3.5F/FUT3.8R and FUT3.6F/ FUT3.9R. The PCR was performed using DNA extracted from blood cells as a template. The $25 \mu$ of final reaction mixture were composed of $2 \mu$ DNA, $2.5 \mu 110 \times$ Taq polymerase buffer, $25 \mathrm{pmol}$ of each primer, $3 \mu \mathrm{l}$ dNTPs $(20 \mathrm{mM})$ and $1 \mu \mathrm{l}$ Taq polymerase (Perkin Elmer). After 5 min of DNA denaturation at $95^{\circ} \mathrm{C}, \mathrm{PCR}$ was performed for 35 cycles: DNA denaturation, $94^{\circ} \mathrm{C}, 30 \mathrm{~s}$; annealing of primers at $70^{\circ} \mathrm{C}, 30 \mathrm{~s}$, and elongation at $72^{\circ} \mathrm{C}, 1 \mathrm{~min}$; with a final extension at $72^{\circ} \mathrm{C}$ for $10 \mathrm{~min}$. The annealing temperature for the $3 \mathrm{rd}, 4 \mathrm{th}$ and 5 th set of primers was $64^{\circ} \mathrm{C}$. The PCR products were verified by electrophoresis in 1\% agarose gel and then extracted using a Gel Extraction Kit (QIAGEN).

Single strand conformational pattern (SSCP)

Separation of single strand DNA was performed by electrophoresis in $0.8 \%$ MDE (BMA products) gel in Tris-Borate-EDTA (TBE) buffer (Sambrook et al. 1989). The electrophoresis was performed over $15 \mathrm{~h}$ under two different temperatures, $20^{\circ} \mathrm{C}$ and $6^{\circ} \mathrm{C}$. The gels were stained by the $\mathrm{AgNO}_{3}$ staining method.

Sequencing of FUT3 gene fragments

The FUT3 gene fragments generated by PCR were purified and used as templates for the sequencing assays. Each sequencing reaction was performed in a final volume of $5 \mu \mathrm{l}: 2 \mu \mathrm{l}$ of DNA template, 3 pmol of primer and $2 \mu \mathrm{l}$ of TRR mix (ABI Prism, Applied Biosystem). The sequencing PCR was performed for 30 cycles: DNA denaturation, $94^{\circ} \mathrm{C}, 30 \mathrm{~s}$; annealing of primers at $50^{\circ} \mathrm{C}, 30 \mathrm{~s}$, and elongation at $60^{\circ} \mathrm{C}, 4 \mathrm{~min}$, with a final extension at $60^{\circ} \mathrm{C}$ for $20 \mathrm{~min}$. The sequenced products were analysed in the ABI Prism 3100 Sequencer (Applied Biosystem).
Table 1 Sequences of the primers used to amplify FUT3 gene fragments

\begin{tabular}{|c|c|c|c|}
\hline & Primer sequence $5^{\prime}-3^{\prime}$ & FUT3 gene fragment & Annealing $T\left({ }^{\circ} \mathrm{C}\right)$ \\
\hline FUT3 $1 F$ & CCATGGCGCCGCTGTCTGGCCGCAC & $33 \mathrm{bp}-227 \mathrm{bp}$ & 70 \\
\hline FUT3 $2 R$ & CAGGGATGTGGAAAGGCCATGTCC & & \\
\hline FUT3 $2 F$ & GGACATGGCCTTTCCACATCCCTG & $203 \mathrm{bp}-474 \mathrm{bp}$ & 70 \\
\hline FUT3 $4 R$ & GGACATGGTCAGATTGAAGTATCTGTCC & & \\
\hline FUT3 $3 F$ & GGACAGATACTTCAATCTGACCATGTCC & $446 \mathrm{bp}-688 \mathrm{bp}$ & 64 \\
\hline FUT3 $6 R$ & GCAGGGGCTTGTGGGAGCGTC & & \\
\hline FUT3 $4 F$ & GACGCTCCCACAAGCCCCTGC & $667 \mathrm{bp}-880 \mathrm{bp}$ & 64 \\
\hline FUT3 $7 R$ & CCACGTGGATGAAGGCGTCGGG & & \\
\hline FUT3 $5 F$ & CCCGACGCCTTCATCCACGTGG & 859 bp-1086-bp & 64 \\
\hline FUT3 $8 R$ & TCAGGTGAACCAAGCCGCT & & \\
\hline FUT3 $6 F$ & CCCGACGCCTTCATCCACGT & 859 bp-1157bp & 64 \\
\hline FUT3 $9 R$ & CCACAAAGGACTCCAGCAGG & & \\
\hline
\end{tabular}


Immunohistochemistry

Endoscopic gastric biopsies $(n=47)$ were obtained from all the individuals after informed consent (Figueiredo et al. 2001; Silva et al. 2001). Tissues were embedded in paraffin and serial $4 \mu \mathrm{m}$ sections were obtained for immunohistochemistry. Monoclonal antibodies were used to detect type 1 chain carbohydrate antigens, Ca3F4 (Young et al. 1981) to detect Le ${ }^{\mathrm{a}}$ and BG6 (Signet Pathology Systems) to detect Le ${ }^{\mathrm{b}}$. Paraffin sections were deparaffinated and rehydrated. In all sections endogenous peroxidase was blocked using $0.5 \%$ hydrogen peroxide $\left(\mathrm{H}_{2} \mathrm{O}_{2}\right)$ in methanol for $30 \mathrm{~min}$, at room temperature. Sections were washed twice in TBS, incubated with rabbit normal serum, diluted $1: 10$ in bovine serum albumin (BSA) $10 \%$ for $20 \mathrm{~min}$ and then incubated overnight, at $4^{\circ} \mathrm{C}$, with the primary antibodies (Ca3F4 and BG6). Sections were rinsed in water, incubated for $30 \mathrm{~min}$ with the secondary antibody, biotinlabelled rabbit anti-mouse serum, diluted 1:200 in BSA 5\%, rinsed in TBS and incubated with avidin-biotin-peroxidase complex for $1 \mathrm{~h}$. Slides were washed three times in TBS before staining with

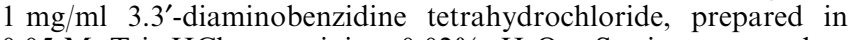
$0.05 \mathrm{M}$ Tris- $\mathrm{HCl}$, containing $0.02 \% \quad \mathrm{H}_{2} \mathrm{O}_{2}$. Sections were then stained with hematoxylin, dehydrated and mounted in Entellan.

Statistical analysis

Statistical analysis was performed using Fisher's exact test.

\section{Results}

Description of polymorphisms

for each 5' FUT3 fragment

Analysis of the first $5^{\prime}$ FUT3 gene fragment (33 bp$227 \mathrm{bp}$ ) by SSCP showed six distinct migration patterns. Sequencing of PCR fragments obtained from representative samples from the six patterns, showed two polymorphisms (59T $>\mathrm{G}$ and $202 \mathrm{~T}>\mathrm{C}$ ). The six SSCP patterns represent: normal genotype (1); Heterozygous $202 \mathrm{~T}>\mathrm{C}$ (2); Heterozygous 59T $>\mathrm{G} / 202 \mathrm{~T}>\mathrm{C}$ (3);

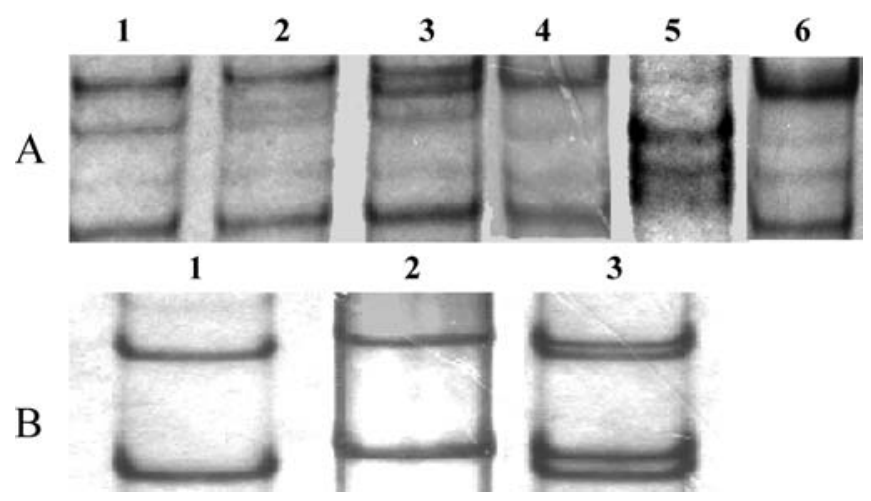

Fig. 1 A SSCP patterns obtained for the first 5' FUT3 gene fragment (33 bp-227 bp) in individuals with normal genotype (1), Heterozygous 202T $>\mathrm{C}$ genotype (2), Heterozygous 59T $>\mathrm{G} /$ $202 \mathrm{~T}>\mathrm{C}$ genotype (3), Homozygous 59T $>\mathrm{G}$ genotype (4) and Homozygous 202T $>\mathrm{C}$ genotype (5) Homozygous 59T $>\mathrm{G} / \mathrm{Het}-$ erozygous202T $>$ C (6). B SSCP patterns obtained for the second $5^{\prime}$ FUT3 gene fragment (203 bp-474 bp) in individuals with normal genotype (1), Homozygous $314 \mathrm{C}>\mathrm{T}$ genotype (2) and Heterozygous $314 \mathrm{C}>\mathrm{T}$ genotype (3)
Homozygous 59T $>$ G (4); Homozygous 202T $>\mathrm{C}$ (5), and Homozygous 59T $>\mathrm{G} /$ Heterozygous $202 \mathrm{~T}>\mathrm{C}(6)$ (Fig. 1A). The 59T $>$ G polymorphism was found in 33 individuals, in 11 cases it was homozygous and in 22 cases it was heterozygous (Fig. 2), which represents an allele frequency of 0.47 . The $202 \mathrm{~T}>\mathrm{C}$ polymorphism was found in 35 individuals, all except one were heterozygous (Fig. 2), which represents an allele frequency of 0.38 .

The second 5' FUT3 gene fragment (203 bp-474 bp) showed three distinct patterns by SSCP. Sequencing of the PCR fragments from representative samples of the three patterns showed one polymorphism $(314 \mathrm{C}>\mathrm{T})$. The three patterns represent: normal genotype (1); Homozygous $314 \mathrm{C}>\mathrm{T}$ genotype (2), and Heterozygous $314 \mathrm{C}>\mathrm{T}$ genotype (3) (Fig. 1B). The $314 \mathrm{C}>\mathrm{T}$ polymorphism was found in 35 individuals, in 12 cases it was homozygous and in 23 cases it was heterozygous (Fig. 2), which represents an allele frequency of 0.50 .

Analysis of fragments 3, 4 and 5 by SSCP did not show consistent patterns of migration under all the assayed conditions. We therefore analysed fragments 3,4 and 5 by direct sequencing of all the samples.

For the third FUT3 gene fragment (446 bp-688 bp), we found the $508 \mathrm{G}>\mathrm{A}$ polymorphism in 13 individuals, 4 individuals were $508 \mathrm{G}>\mathrm{A}$ homozygous and 9 were $508 \mathrm{G}>\mathrm{A}$ heterozygous (Fig. 2), which represents an allele frequency of 0.18 .

The fourth and the fifth $5^{\prime}$ FUT3 gene fragments, $667 \mathrm{bp}-880 \mathrm{bp}$ and $859 \mathrm{bp}-1086 \mathrm{bp}$, respectively, showed one polymorphism, 1067T $>\mathrm{A}$. This alteration, $1067 \mathrm{~T}>\mathrm{A}$, was found in 10 individuals, in 6 cases $1067 \mathrm{~T}>\mathrm{A}$ polymorphism was homozygous and in 4 cases it was heterozygous (Fig. 2), which represents an allele frequency of 0.17 .

We have found 14 different profiles of FUT3 gene polymorphisms that are described and depicted in Table 2. Profile $(59 \mathrm{~T}>\mathrm{G} 202 \mathrm{~T}>\mathrm{C} 314 \mathrm{C}>\mathrm{T}$ ) was the most common and was observed in $28 \%$ of the cases.

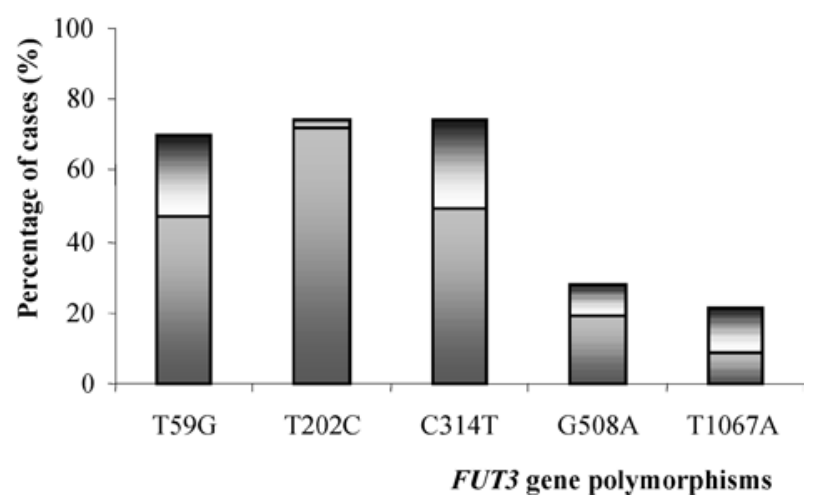

Fig. 2 Percentage of cases with each polymorphism, 59T $>$ G, $202 \mathrm{~T}>\mathrm{C}, 314 \mathrm{C}>\mathrm{T}, 508 \mathrm{G}>\mathrm{A}$ and $1067 \mathrm{~T}>\mathrm{A}$. The bars represent the percentage of homozygous individuals (above line) and heterozygous individuals for each polymorphism (below line) 
Table 2 Patterns of FUT3 gene polymorphisms and Lewis phenotype in gastric mucosa

\begin{tabular}{|c|c|c|c|}
\hline $\begin{array}{l}\text { Lewis in peripheral } \\
\text { blood }\left(\mathrm{Le}^{\mathrm{a}} \text { and } / \text { or } \mathrm{Le}^{\mathrm{b}}\right)\end{array}$ & $\begin{array}{l}\text { Lewis in gastric } \\
\text { mucosa }\left(\mathrm{Le}^{\mathrm{a}} \text { and/or } \mathrm{Le}^{\mathrm{b}}\right)\end{array}$ & Profiles of FUT3 gene polymorphisms & $\begin{array}{l}\text { No of } \\
\text { individuals }\end{array}$ \\
\hline Absent & Present & $\begin{array}{l}\text { Homozygous 202T }>\mathrm{C} / 314 \mathrm{C}>\mathrm{T} \\
\text { Heterozygous 59T }>\mathrm{G} / 202 \mathrm{~T}>\mathrm{C} / 314 \mathrm{C}>\mathrm{T} \\
\text { Heterozygous 202T }>\mathrm{C} \text { Homozygous } 314 \mathrm{C}>\mathrm{T} \\
\text { Heterozygous 202T }>\mathrm{C} \text { Homozygous } 314 \mathrm{C}>\mathrm{T} / 508 \mathrm{G}>\mathrm{A} \\
\text { Homozygous 59T }>\mathrm{G} \text { Heterozygous } 202 \mathrm{~T}>\mathrm{C} / 1067 \mathrm{~T}>\mathrm{A} \\
\text { Heterozygous 59T }>\mathrm{G} / 202 \mathrm{~T}>\mathrm{C} \text { Homozygous } 314 \mathrm{C}>\mathrm{T} \\
\text { Homozygous 1067T }>\mathrm{A} \\
\text { Heterozygous 59T }>\mathrm{G} / 202 \mathrm{~T}>\mathrm{C} / 314 \mathrm{C}>\mathrm{T} \\
\text { Homozygous 314C }>\mathrm{T} \\
\text { Heterozygous 202T }>\mathrm{C} / 314 \mathrm{C}>\mathrm{T} \text { Homozygous } 1067 \mathrm{~T}>\mathrm{A} \\
\text { Heterozygous 59T }>\mathrm{G} / 202 \mathrm{~T}>\mathrm{C} / 314 \mathrm{C}>\mathrm{T} / 508 \mathrm{G}>\mathrm{A} \\
\text { Heterozygous 59T }>\mathrm{G} / 202 \mathrm{~T}>\mathrm{C} / 314 \mathrm{C}>\mathrm{T} / 1067 \mathrm{~T}>\mathrm{A} \\
\text { Heterozygous 202T }>\mathrm{C} / 314 \mathrm{C}>\mathrm{T} \\
\text { Homozygous 59T }>\mathrm{G} \text { Heterozygous 508G }>\mathrm{A} \\
\text { Heterozygous 59T }>\mathrm{G} / 202 \mathrm{~T}>\mathrm{C} / 314 \mathrm{C}>\mathrm{T} \text { Homozygous } 508 \mathrm{G}>\mathrm{A} \\
\text { Heterozygous 202T }>\mathrm{C} \text { Homozygous } 314 \mathrm{C}>\mathrm{T} \\
\text { Homozygous 59T }>\mathrm{G} / 508 \mathrm{G}>\mathrm{A} \text { Heterozygous 202T }>\mathrm{C} \\
\text { Heterozygous 59T }>\mathrm{G} / 202 \mathrm{~T}>\mathrm{C} \text { Homozygous } 508 \mathrm{G}>\mathrm{A} \\
\text { Homozygous 59T }>\mathrm{G} \\
\text { Homozygous 59T }>\mathrm{G} \text { Heterozygous } 1067 \mathrm{~T}>\mathrm{A} \\
\text { Heterozygous 59T }>\mathrm{G} / 202 \mathrm{~T}>\mathrm{C} / 508 \mathrm{G}>\mathrm{A} \text { Homozygous } 314 \mathrm{C}>\mathrm{T} \\
\text { Heterozygous 59T }>\mathrm{G} / 202 \mathrm{~T}>\mathrm{C} \text { Homozygous } 314 \mathrm{C}>\mathrm{T} \\
\text { Homozygous 59T }>\mathrm{G} \text { Heterozygous } 202 \mathrm{~T}>\mathrm{C} / 314 \mathrm{C}>\mathrm{T} \\
\text { Heterozygous 59T }>\mathrm{G} / 202 \mathrm{~T}>\mathrm{C} / 508 \mathrm{G}>\mathrm{A} \\
\text { Homozygous 59T }>\mathrm{G} \text { Heterozygous } 314 \mathrm{C}>\mathrm{T} / 1067 \mathrm{~T}>\mathrm{A} \\
\text { Heterozygous 202T }>\mathrm{C} / 314 \mathrm{C}>\mathrm{T} / 508 \mathrm{G}>\mathrm{A} \\
\text { Homozygous 59T }>\mathrm{G} / 1067 \mathrm{~T}>\mathrm{A}\end{array}$ & $\begin{array}{l}1 \\
4 \\
1 \\
1 \\
1 \\
1 \\
1 \\
6 \\
2 \\
1 \\
5 \\
1 \\
2 \\
1 \\
1 \\
4 \\
1 \\
1 \\
1 \\
3 \\
1 \\
1 \\
1 \\
1 \\
1 \\
1 \\
2\end{array}$ \\
\hline
\end{tabular}

Table 3 FUT3 polymorphism profiles and Lewis phenotype in gastric mucosa

${ }^{\text {a }}$ Homozygous for any of the deleterious polymorphisms, $202 \mathrm{~T}>\mathrm{C}, 508 \mathrm{G}>\mathrm{A}$ and $1067 \mathrm{~T}>\mathrm{A}$

\begin{tabular}{llcr}
\hline & Lewis negative $n(\%)$ & Lewis positive $n(\%)$ & Total \\
\hline Homozygous for deleterious polymorphisms $^{\mathrm{a}}$ & $2(22.2)$ & $7(77.8)$ & 9 \\
Homozygous 59T $>\mathrm{G}$ & $1(12.5)$ & $7(87.5)$ & 8 \\
Homozygous 314C $>\mathrm{T}$ & $2(20.0)$ & $8(80.0)$ & 10 \\
Heterozygous & $4(20.0)$ & $16(80.0)$ & 20 \\
\hline
\end{tabular}

FUT3 polymorphism patterns and Le phenotype in gastric mucosa

The study of gastric biopsies by immunohistochemistry showed that only 9 of the 47 individuals evaluated by immunohistochemistry $(19 \%)$ were negative for Lewis antigen expression both in the tissues and in the red blood cells. The other 38 individuals showed expression of Lewis antigens in the tissues despite the blood Lewis negative phenotype (Table 2). Due to the extensive number and complexity of the polymorphism profiles observed for each individual (Table 2), we decided to group the cases in the following categories: homozygous for deleterious polymorphisms $(202 \mathrm{~T}>\mathrm{C}, 508 \mathrm{G}>\mathrm{A}$ and $1067 \mathrm{~T}>\mathrm{A}$ ); homozygous for $59 \mathrm{~T}>\mathrm{G}$; homozygous for $314 \mathrm{C}>\mathrm{T}$, and cases that do not have homozygosity for any of the polymorphisms. Table 3 shows the Lewis expression in the gastric mucosa according to the recoded polymorphism profiles. Seven of the nine cases with homozygosity for deleterious polymorphisms showed expression of Lewis antigens in the gastric mucosa, in contrast to theoretical expectations. One of the cases homozygous for $59 \mathrm{~T}>\mathrm{G}$, two of the cases homozygous for $314 \mathrm{C}>\mathrm{T}$ and four of the cases heterozygous for all the polymorphisms did not show Lewis antigen expression in the gastric mucosa. Two identical polymorphism profiles were observed both in Lewis negative and Lewis positive cases in the group of homozygous for $314 \mathrm{C}>\mathrm{T}$ polymorphism (two cases) and in the group of the heterozygous (ten cases) (Table 2 and Fig. 3). The polymorphism profiles of these cases (Tables 2 and 3 ) are complex and possible interpretations will be addressed in the discussion.

\section{H. pylori infection and Lewis expression/polymorphism}

In the present series most of the individuals were infected by H. pylori (95.0\%) (Nogueira et al. 2001). No significant differences were observed between the presence and severity of $H$. pylori infection (Table 4) as well as the presence of atrophic gastritis and intestinal metaplasia and the Lewis positive/negative phenotype (data not shown). 
Fig. 3A-D FUT3

polymorphism profiles with both Lewis negative and Lewis positive individuals in gastric mucosa, $a / b$ : SSCP patterns for cases 1 and 2 (Heterozygous $59 \mathrm{~T}>\mathrm{G} / 202 \mathrm{~T}>\mathrm{C} / 314 \mathrm{C}>\mathrm{T})$; $\mathbf{A}$ Lewis negative gastric mucosa for case 1; B Lewis positive gastric mucosa for case $2 ; c / d$ : SSCP patterns for cases 3 and 4 (Heterozygous 59T $>\mathrm{G} /$ $202 \mathrm{~T}>\mathrm{C}$ and Homozygous $314 \mathrm{C}>\mathrm{T}$ ); $\mathbf{C}$ Lewis negative gastric mucosa for case 3 , and D Lewis positive gastric mucosa for case 4

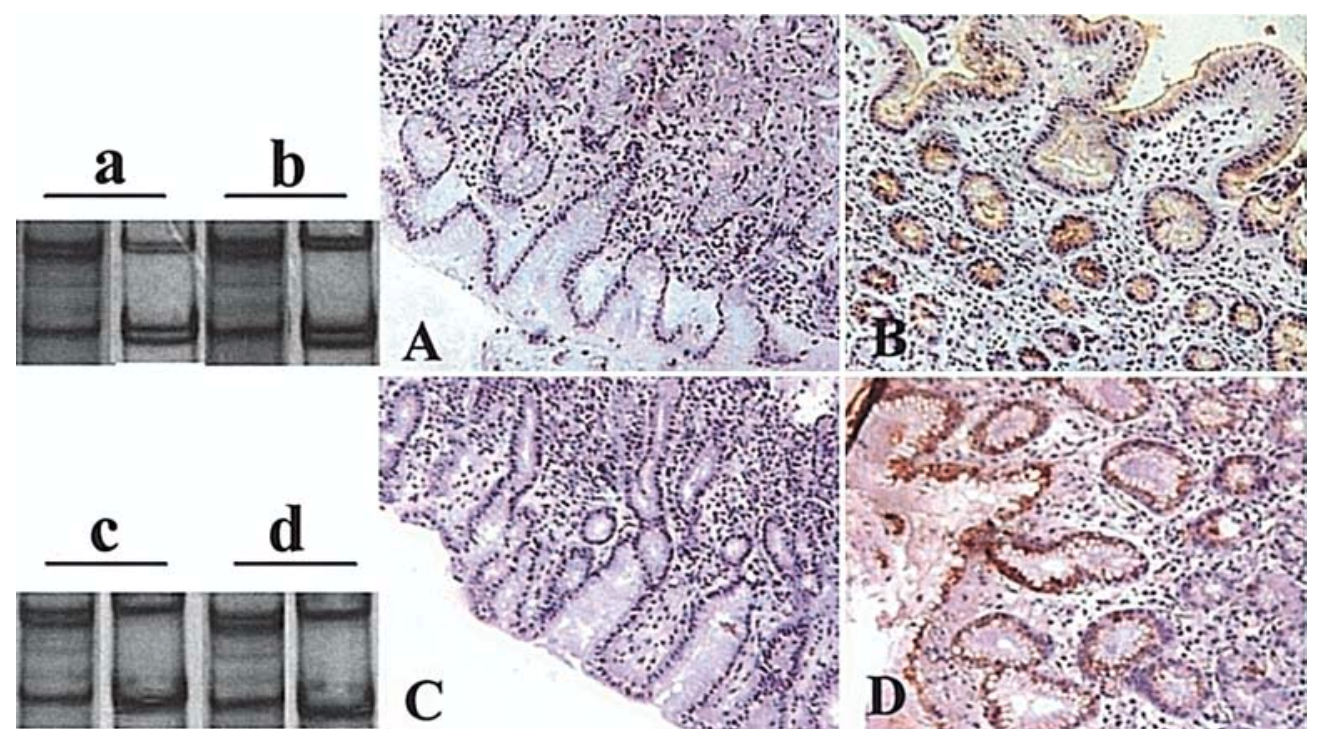

\section{Discussion}

In the present study we identified five polymorphisms of the FUT3 gene in 47 Portuguese individuals that have a Lewis negative blood group phenotype $(10.2 \%$ of 460 individuals evaluated). All the polymorphisms we have identified were previously reported in other populations (Elmgren et al. 1993, 1996; Koda et al. 1993; Nishihara et al. 1994; Ørntoft et al. 1996; Pang et al. 1996).

The frequency of Lewis negative blood group phenotype we have observed $(10.2 \%)$ is very similar to the frequency $(10 \%)$ reported by Watkins (1980) in Caucasians. This indicates that polymorphisms inactivating the FucT III enzyme have a similar and relatively low prevalence in the populations evaluated so far.

Three of the FUT3 polymorphisms were identified at a high frequency within the Lewis negative population: $59 \mathrm{~T}>\mathrm{G}(0.47), 202 \mathrm{~T}>\mathrm{C}(0.38)$ and $314 \mathrm{C}>\mathrm{T}(0.50)$. The three polymorphisms are described in all the populations previously studied (Elmgren et al. 1993, 1996; Koda et al. 1993; Liu et al. 1999; Mollicone et al. 1994; Nishihara et al. 1994; Ørntoft et al. 1996) and their frequency, whenever it was evaluated, was similar to the one we observed in the present study: 59T $>\mathrm{G}$ was observed with an allele frequency of 0.43 in 15 cases; $314 \mathrm{C}>\mathrm{T}$ was observed with an allele frequency of 0.57 in 15 cases of individuals from Denmark (Elmgren et al. 1996). Polymorphism 202T $>\mathrm{C}$ has a higher allele frequency in Denmark (0.60) (Elmgren et al. 1996).

Individuals homozygous for $59 \mathrm{~T}>\mathrm{G}$ polymorphism were observed both in Lewis negative and in Lewis positive cases at the tissue expression level (see Table 2). This is partly in agreement with the evidence showing that the mutant enzyme has the same affinity $\left(K_{\mathrm{m}}\right)$ as the wild type enzyme (Mollicone et al. 1994). The reduced enzyme activity in vivo can be due to an inappropriate localisation of the enzyme in the Golgi since it affects the transmembrane domain (Ørntoft et al. 1996). The pres-
Table $4 H$. pylori infection and Lewis expression in gastric mucosa

\begin{tabular}{|c|c|c|c|c|}
\hline & \multicolumn{4}{|c|}{ H. pylori colonisation } \\
\hline & - & + & ++ & +++ \\
\hline Lewis positive $^{\mathrm{a}}$ & 18 & $\begin{array}{l}32 \\
(9.1 \%)\end{array}$ & $\begin{array}{l}140 \\
(39.9 \%)\end{array}$ & $\begin{array}{l}161 \\
(45.9 \%)\end{array}$ \\
\hline Lewis negative $^{\mathrm{b}}$ & $(0.0 \%)$ & $(0.0 \%)$ & $\begin{array}{c}4 \\
(44.4 \%)\end{array}$ & $\begin{array}{c}5 \\
(55.6 \%)\end{array}$ \\
\hline
\end{tabular}

${ }^{a}$ Includes all cases with Lewis blood positive phenotype as well as all cases that despite having a Lewis negative blood phenotype have Lewis expression in the gastric mucosa

${ }^{\mathrm{b}}$ Includes nine Lewis negative cases in blood and in gastric mucosa

ence of homozygous 59T $>\mathrm{G}$ individuals in the Lewis negative cases can be explained by the coexistence in all these cases of other polymorphisms that abrogate enzyme activity.

The other two polymorphisms that we identified $(202 \mathrm{~T}>\mathrm{C}$ and $314 \mathrm{C}>\mathrm{T})$ are localised in the catalytic domain and are associated with a negative Lewis phenotype in Sweden (De Vries et al. 1995; Elmgren et al. 1996) and in Denmark (Ørntoft et al. 1996). Curiously, De Vries et al. (1995) showed that the $314 \mathrm{C}>\mathrm{T}$ polymorphism has enzymatic activity similar to wild type enzyme when it catalyses the Le antigens synthesis on glycoprotein acceptors. Both in Sweden and in Denmark $202 \mathrm{~T}>\mathrm{C}$ and $314 \mathrm{C}>\mathrm{T}$ polymorphisms co-localised in the same allele (Elmgren et al. 1996; Ørntoft et al. 1996). Although we did not study polymorphism profiles of individual alleles, we have identified individuals that carry the $202 \mathrm{~T}>\mathrm{C}$ polymorphism alone (four individuals - Table 2) or the $314 \mathrm{C}>\mathrm{T}$ polymorphism alone (three individuals - Table 2).

The two other polymorphisms, 508G $>\mathrm{A}$ and $1067 \mathrm{~T}>\mathrm{A}$, we have identified have already been described in Indonesian (Mollicone et al. 1994), Japanese (Koda et al. 1993; Nishihara et al. 1994), Swedish (Elmgren et al. 1996) and Danish (Ørntoft et al. 1996) 
populations. Both $508 \mathrm{G}>\mathrm{A}$ and $1067 \mathrm{~T}>\mathrm{A}$ polymorphisms were observed with a low frequency in our series ( 0.18 and 0.17 , respectively); in the series of Elmgren et al. (1996) these two polymorphisms were found with a frequency of 0.07 and 0.30 , respectively. Both $508 \mathrm{G}>\mathrm{A}$ and $1067 \mathrm{~T}>\mathrm{A}$ polymorphisms affect the sequence of the catalytic domain and are deleterious for enzyme activity (Ørntoft et al. 1996).

The high homology between FUT3 and FUT6 genes may be responsible for the technical problems found in SSCP to separate the fourth and the fifth FUT3 gene fragments. We observed the $1007 \mathrm{~A}>\mathrm{C}$ and $1029 \mathrm{~A}>\mathrm{G}$ alterations (data not shown), previously reported by Nishihara et al. (1993) as polymorphisms and after that called by the same authors as Taq polymerase artefacts (Nishihara et al. 1994). By comparing the sequence of the FUT3 and FUT6 genes, we verified that $1007 \mathrm{~A}>\mathrm{C}$ alteration corresponds to the 1004 nucleotide from FUT6. Other alterations were also found in the present study that correspond to the sequence of FUT6 (data not shown).

The comparison we have performed between FUT3 polymorphism profiles in Lewis negative blood phenotype individuals and the gastric tissue Lewis expression profile has not, to the best of our knowledge, been previously performed. The first interesting finding is that most cases (38 of 47 cases) have gastric tissue expression of Lewis antigens despite a Lewis negative blood phenotype. The expression of Lewis antigens in $81 \%$ of cases shows that although our population has a frequency of blood Lewis negative individuals expected for Caucasians $(10 \%)$, just $2 \%$ of these individuals are Lewis negative in gastric mucosa. This fits with previous observations (Kobayashi et al. 1993) and probably reflects different FucT III enzyme activities towards different acceptor substrates (e.g. glycolipids vs glycoproteins) (De Vries et al. 1995). Seven of the cases with a Lewis positive expression profile in the gastric mucosa are homozygous for one of the deleterious polymorphisms $(202 \mathrm{~T}>\mathrm{C}, 508 \mathrm{G}>\mathrm{A}$ or $1067 \mathrm{~T}>\mathrm{A})$ (Table 3). This observation suggests that fucosyltransferases other than FucT III can catalyse, in gastric tissues, the $\alpha 1,4$ fucosyltransferase activity necessary to build $\mathrm{Le}^{\mathrm{a}}$ and $\mathrm{Le}^{\mathrm{b}}$ structures. A candidate gene product capable, in vitro, to build $\mathrm{Le}^{\mathrm{a}}$ and $\mathrm{Le}^{\mathrm{b}}$ antigens is FucT V (Kokowska-Latallo et al. 1990). Further studies should test the FucT V capability, in vivo, to build the $\mathrm{Le}^{\mathrm{a}}$ and $\mathrm{Le}^{\mathrm{b}}$ antigens. The observation that individuals homozygous for deleterious polymorphisms are either Lewis negative or Lewis positive in the gastric mucosa, indicates that the hypothetical alternative $\alpha 1,4$ fucosyltransferase activity is also subject to inactivating polymorphisms in some individuals.

The nine cases that have a Lewis negative phenotype in the gastric mucosa as well as in the peripheral blood correspond to two cases homozygous for deleterious polymorphisms and seven cases homozygous for noninactivating polymorphisms or heterozygous (Table 3). The two cases with homozygosity for deleterious polymorphisms have, as discussed in the previous paragraph, a good reason for the negative Lewis phenotype in the mucosa. In one of the other seven cases (Table 2), the inactivation of Lewis enzyme can be explained by allelic combination, since this individual is heterozygous for two deleterious polymorphisms $(202 \mathrm{~T}>\mathrm{C}$ and $1067 \mathrm{~T}>\mathrm{A})$. The other six cases do not have more than one inactivating polymorphism either in homo or in heterozygosity. In these six cases the evidence from in vitro experiments would predict the maintenance of enzyme activity and the expression of Lewis antigens. Our data clearly show that either the in vitro studies are not accurate to predict the in vivo situation or that we are not taking in account aspects of regulation of gene expression that may affect enzyme expression/activity in normal and pathological conditions.

The absence of relationship we have observed between the Lewis polymorphisms and the presence of $H$. pylori infection is in disagreement with the recent study by Ikehara et al. (2001), and suggests that, at least in a population with a high rate of $H$. pylori infection, the Lewis polymorphism does not affect the presence or absence of infection.

Acknowledgements We thank Fundação para a Ciência e a Tecnologia and Programa Operacional Ciência, Tecnologia, Inovação do Quadro Comunitário de Apoio III.The authors are grateful to the following departments where patients' data and samples were collected: Estaleiros Navais de Viana do Castelo, Departments of Surgery 3, Gastroenterology and Immunohemotherapy of Hospital S. João, Porto, Portugal.This work was supported by the Praxis/P/BIO/12072/1998 project from Fundação para a Ciência e a Tecnologia, Administração Regional de Saúde do Norte, Fundação Calouste Gulbenkian (FC-54918) and the Luso American Foundation for Development.

\section{References}

Boren T, Falk P, Roth KA, Larson G, Normark S (1993) Attachment of Helicobacter pylori to human gastric epithelium mediated by blood group antigens. Science 262(5141):1892-1895

Carneiro F, Amado M, Lago P, Taveira-Gomes A, Amil M, Barreira R, Soares J, Pinho C (1996) Helicobacter pylori infection and blood groups. Am J Gastroenterol 91(12):2646-2647

Clyne M, Drumm B (1997) Absence of effect of Lewis A and Lewis B expression on adherence of Helicobacter pylori to human gastric cells. Gastroenterology 113(1):72-80

De Vries T, Srnka CA, Palcic MM, Swieller SJ, van der Eijnden DH, Macher BA (1995) Acceptor specificity of different length constructs of human recombinant $\alpha 1,3 / 1,4$-fucosyltransferases. J Biol Chem 270:8712-8722

Dixon MF, Genta RM, Yardley JH, Correa P (1996) Classification and grading of gastritis. The updated Sydney system. Am J Surg Pathol 20:1161-1181

Elmgren A, Rydberg L, Larson G (1993) Genotypic heterogeneity among Lewis negative individuals. Biochem Biophys Res Commun 196(2):515-520

Elmgren A, Mollicone R, Costache M, Börjeson C, Oriol R, Harrington J, Larson G (1996) Significance of individual polymorphisms, T202C and C314T, in the Human Lewis (FUT3) gene for expression of Lewis antigens by the Human $\alpha(1,3 / 1,4)$-fucosyltransferase, Fuc-TIII. J Biol Chem 272:21994 21998 
Elmgren A, Börjeson C, Svensson L, Rydberg L, Larson G (1997) DNA sequencing and screening for polymorphisms in the Human Lewis (FUT3) gene enables molecular genotyping of the Human Lewis blood group system. Vox Sang 70:97-103

Figueiredo C, Van Doorn LJ, Nogueira C, Soares JM, Pinho C, Figueira P, Quint WG, Carneiro F (2001) Helicobacter pylori genotypes are associated with clinical outcome in Portuguese patients and show a high prevalence of infections with multiple strains. Scand J Gastroenterol 36(2):128-135

Gerhard M, Lehn N, Neumayer N, Borén T, Rad R, Schepp W, Miehlke S, Classen M, Prinz C (1999) Clinical relevance of the Helicobacter pylori gene for blood-group antigen-binding adhesin. PNAS 96(22):12779-12783

Heneghan MA, Moran AP, Feeley KM, Egan EL, Goulding J, Connolly CE, McCarthy CF (1998) Effect of host Lewis and ABO blood group antigen expression on Helicobacter pylori colonisation density and the consequent inflammatory response. Immunol Med Microbiol 20(4):257-266

Ikehara Y, Nishihara S, Yasutomi H, Kitamura T, Matsuo K, Shimizu N, Inada K I, Kodera Y, Yamamura Y, Narimatsu H, Hamajima N, Tatematsu M (2001) Polymorphisms of two fucosyltransferase genes (Lewis and secretor genes) involving Type I Lewis antigens are associated with the presence of anti- $H$ pylori IgG antibody. Cancer Epidemiol Biomarkers Prev 10:971-977

Ilver D, Arnqvist A, Ogren J, Frick I M, Kersulyte D, Incecik E T, Berg D E, Covacci A, Engstrand L, Boren T (1998) Helicobacter pylori adhesin binding fucosylated histo-blood group antigens revealed by retagging. Science 279 (5349):373-377

Klaamas K, Kurtenkov O, Ellamaa M, Wadstrom T (1997) The Helicobacter pylori seroprevalence in blood donors related to Lewis $(\mathrm{a}, \mathrm{b})$ histo-blood group phenotype. Eur J Gastroenterol Hepatol 9(4):367-370

Kobayashi K, Sakamoto J, Kito T, Yamamura Y, Koshikawa T, Fujita M, Watanabe T, Nakazato H (1993) Lewis blood grouprelates antigen expression in normal gastric epithelium, intestinal metaplasia, gastric adenoma and gastric carcinoma. Am J Gastroenterol 88(6):919-924

Koda Y, Kimura H, Mekada E (1993) Analysis of Lewis fucosyltransferase genes from the human gastric mucosa of Lewispositive and -negative individuals. Blood 82(9):2915-2919

Kokowska-Latallo JF, Larsen RD, Nair RP, Lowe JB (1990) A cloned human cDNA determines expression of a mouse stagespecific embryonic antigen and the Lewis blood group alpha(1,3/1,4)fucosyltransferase. Genes Dev 4:1288-1303

Liu YH, Koda Y, Soejima M, Pang H, Wang B, Kimura H (1999) Lewis (FUT3) genotypes in two different Chinese populations. J Forensic Sci 44(1):82-86

Mollicone R, Reguigne I, Kelly RJ, Fletcher A, Watt J, Chatfield S, Aziz A, Cameron HS, Weston BW, Lowe JB (1994) Molecular basis for Lewis alpha $(1,3 / 1,4)$-fucosyltransferase gene deficiency (FUT3) found in Lewis-negative Indonesian pedigrees. J Biol Chem 269(33):20987-20994

Narimatsu H (1994) Recent progress in molecular cloning of glycosyltransferase genes of eukaryotes. Microbiol Immunol 38(7):489-504

Narimatsu H, Iwasaki IL, Nishiara S, Kimura H, Kudo T, Yamauchi Y, Hiroashi S (1996) Genetic evidence for the Lewis enzyme, which synthesizes typy-1 Lewis antigens in colon tissue, and intracellular localization of the enzyme. Cancer Res 56:330-338

Nishihara S, Yazawa S, Iwasaki H, Nakazato M, Kudo T, Ando T, Narimatsu H (1993) Alpha $(1,3 / 1,4)$ fucosyltransferase (FucTIII) gene is inactivated by a single amino acid substitution in Lewis histo-blood type negative individuals. Biochem Biophys Res Commun 196(2):624-631
Nishihara S, Narimatsu H, Iwasaki H, Yazawa S, Akamatsu S, Ando T, Seno T, Narimatsu I (1994) Molecular genetic analysis of the human Lewis histo-blood group system. J Biol Chem 269(46):29271-29278

Nishihara S, Hiraga T, Ikehara Y, Iwasaki, H, Kudo, T, Yazawa, S, Morozumi, K, Suda, Y, Narimatsu, H (1999) Molecular behaviour of mutant Lewis enzymes in vivo. Glycobiology 9(4):373-382

Niv Y, Fraser G, Delpre G, Neeman A, Leiser A, Samra Z, Scapa E, Gilon E, Bar-Shany S (1996) Helicobacter pylori infection and blood groups. Am J Gastroenterol 91(1):101-104

Nogueira C, Figueiredo C, Carneiro F, David L, Peixoto A, Oliveira AC, Gomes AT, Barreira R, Tomé-Ribeiro A, Salgado C, Figueira P, Belo L, Ribeiro AM, Lomba MF, Monteiro ML, Nina N, Gonçalves G, Quint WGV, Van Doorn LJ, Sobrinho Simões M (2000) Associação entre os genótipos de Helicobacter pylori e o desenvolvimento de gastrite crónica atrófica e metaplasia intestinal Primeiros resultados de uma acção de rastreio. J Portug Gastroenterol 7:138-145

Nogueira C, Figueiredo C, Carneiro F, Gomes AT, Barreira R, Figueira P, Salgado C, Belo L, Peixoto A, Bravo JC, Bravo LE, Realpe JL, Plaisier AP, Quint WG, Ruiz B, Correa P, van Doorn LJ (2001) Helicobacter pylori genotypes may determine gastric histopathology. Am J Pathol 158(2):647-654

Oriol R, Le Pendu J, Mollicone R (1986) Genetics of ABO, H, Lewis, $\mathrm{X}$ and related antigens. Vox Sang 51(3):161-171

Ørntoft T, Vestergaard EM, Holmes E, Jakobsen JS, Grunnet N, Mortensen M, Johnson P, Bross P, Gregersen N, Skorstengaard $\mathrm{K}$, Jensen UB, Bolund L Wolf H (1996) Influence of Lewis $\alpha 1$ 3/4-L-fucosyltransferase (FUT3) gene polymorphisms on enzyme activity, erythrocyte phenotyping, and circulating tumor marker sialyl-Lewis a levels. J Biol Chem 271:32260-32268

Oberhuber G, Kranz A, Dejaco C, Dragosics B, Mosberger I, Mayr W, Radaszkiewicz T (1997) Blood groups Lewis (b) and $\mathrm{ABH}$ expression in gastric mucosa, lack of inter-relation with Helicobacter pylori colonisation and occurrence of gastric MALT lymphoma. Gut 41(1):37-42

Pang H, Koda Y, Soejima M, Kimura H (1996) Significance of each of three polymorphisms, G484A, G667A, and G808A, present in an inactive allele of the human Lewis gene (FUT3) for $\alpha(1,3 / 1,4)$ fucosyltransferase inactivation. Glycoconjugate 15:961-967

Pang H, Liu Y, Koda Y, Soejima M, Jia J, Schlaphoff T, du Toit ED, Kimura H (1998) Five novel polymorphisms of the Lewis gene (FUT3) in African (Xhosa) and Caucasian populations in South Africa. Hum Genet 102:675-680

Sambrook J, Fritsch EF, Maniatis T (1989) Molecular cloning. A laboratory manual, vol 1. CSH-Laboratory Press, p 66

Schenkel-Brunner H (1995) Human blood groups. Springer, Berlin Heidelberg New York

Silva F, Carvalho F, Peixoto A, Seixas M, Almeid R, Carneiro F, Mesquita P, Figueiredo C, Nogueira C, Swallow DM, Amorim A, David L (2001) MUC1 gene polymorphism in the gastric carcinogenesis pathway. Eur J Hum Genet 9(7):548-552

Umlauft F, Keeffe EB, Offner F, Weiss G, Feichtinger H, Lehmann E, Kilga-Nogler, S, Schwab G, Propst A, Grussnewald K, Judmaier G (1996) Helicobacter pylori infection and blood group antigens, lack of clinical association. Am J Gastroenterol 91(10):2135-2138

Watkins WM (1980) Biochemistry and genetics of the, ABO, Lewis and P blood group systems. Adv Hum Genet 10:1-136

Young Jr WW, Portoukalian J, Hakomori S (1981) Two monoclonal anticarbohydrate antibodies directed to glycosphingolipids with a lacto- $N$-glycosyl type II chain. J Biol Chem 256:1096710972 